Article

\title{
Reconsidering Sheltered Workshops in Light of the United Nations Convention on the Rights of Persons with Disabilities (2006)
}

\author{
Charlotte May-Simera \\ Centre for Disability Law and Policy, National University of Ireland, H91 TK33 Galway, Ireland; \\ c.may-simera1@nuigalway.ie; Tel.: +353-85-27-32-632
}

Received: 12 October 2017; Accepted: 14 December 2017; Published: 5 February 2018

\begin{abstract}
Sheltered work and related practices remain a prevalent service for people with intellectual disabilities. However, as a result of being placed in these, participants overwhelmingly remain segregated and excluded from their wider communities. This paper explores whether, with the advent of the United Nations Convention on the Rights of Persons with Disabilities, we can at least begin to assess the equality implications of such placements and argue that the experience of segregation itself represents numerous rights violations and discrimination. Having considered traditional equality mechanisms and their bearing on people with intellectual disabilities, this discussion explores how far the Convention's re-envisioning of the basic principles of equality can perhaps provide a more promising outlook and ideological stance. Indeed, during the Convention's inception, the negotiations circled around the conflicting opinions as to the purpose, usefulness, and future of sheltered work, revealing the existing tensions between protection and autonomy, shrouding all disability policy discussions. As a result, the question of sheltered work is not explicitly addressed in the treaty and the Committee on the Rights of Persons with Disabilities have been unable to definitively declare that the practice of sheltered work constitutes an act of discrimination. However, the Committee does as times demand that sheltered workshops be phased out where it is obvious that the practice of sheltered work is directly linked to the exploitation of workers. Moreover, certain provisions in the Convention might help in determining wrongful discrimination in some, if limited, instances.
\end{abstract}

Keywords: intellectual disability; sheltered workshops; United Nations Convention on the Rights of Persons with Disabilities; equality; dignity; discrimination

\section{Introduction}

People with intellectual disabilities face considerable barriers in accessing employment in mainstream settings. These are largely attitudinal as well as systematic. Often a robust system of disability services and disability benefit payments, operate to deter people from becoming emancipated and independent from the rigid structures of traditional, all encompassing institutions. As a result, people with intellectual disabilities remain segregated from mainstream society. This paper aims to question this segregation and consider how the practice of placing people with intellectual disabilities in sheltered work settings contributes to their segregation and exclusion.

Specifically, this discussion will address how the widespread segregation of people with intellectual disabilities has persisted in light of evolved conceptions of equality. Arguably this segregation is founded in inequality as the result of unequal treatment. Despite the evolving nature of equality then, its development has not seen an equal regard of all members of society. This failure to encompass some groups of society can perhaps be rectified when we revisit the core purpose of existing human rights frameworks. This involves identifying the main purpose of equality which lies in bestowing upon each individual an equal concern for their inherent dignity. A renewed global 
commitment to equality as presented by the latest international human rights convention adopted in 2006, the United Nations Convention on the Rights of Persons with Disabilities (CRPD; Convention), will be assessed according to its potential to strengthen arguments against segregated policies such as sheltered work.

As the latest human rights treaty and the first to deal with disability specifically, the CRPD was eagerly awaited. The global disability community anticipated that it would bring about a sea change for all persons with disabilities based on its innovative approach to disability equality. Indeed, the treaty did deliver on this front and has prompted a widespread process of disability reform (Quinn 2009). However, some argue that it does not positively impact the lives of all persons with disabilities evenly (Dimopoulos 2010). Others consider that, even though they are equally entitled to benefit from the provisions of the Convention, people with intellectual disabilities have faced marginalization to such an extent that they are often not well placed to gain from its changes (ILO 2011). This paper therefore attempts to test how the Convention will fare in light of the on-going controversy over sheltered workshops and explore how far the treaty may instigate policy changes for people with intellectual disabilities.

\section{The Problem with Sheltered Work}

Before we begin our discussion we should perhaps explore the concept of sheltered work and adopt a working definition of practices included thereunder. This will not only highlight the existing concerns related to the practices but simultaneously also clarify why sheltered work is a suitable example to use in contemplating the reach and strength of the Convention. The act of placing persons in sheltered workshops was predominantly chosen because of its tangible effects experienced overwhelmingly only by persons labeled as having an intellectual disability. Thus, they provide a unique angle from which to address the debate over segregation and its justification. Moreover, the example of sheltered work was chosen based on the prevalence of segregated work and employment policies across the globe. Besides quota systems, sheltered employment, in its varied formats is one of the most widely used employment measures for people with disabilities across Europe (Mallender et al. 2015). Germany and Spain even reported a growth in sheltered workshop placements (Shima et al. 2008; Flores et al. 2011) and Dague (2012) finds that 75\% of adults with intellectual disabilities in the US remained in sheltered work settings despite claims of exploitation (Kennedy 2007; Diament 2011; Cohen 2014). Even international bodies such as the Organization for Economic Co-operation and Development report of the on-going significance and widespread use of segregated employment settings in the wake of controversy (OECD 2003).

Despite their global popularity, there are perhaps as many common markers that denote a similar practice, as there are national, regional and context specific characteristics of the sheltered workshop. Based on the divergent and context-specific approaches, arriving at a distinct definition of sheltered work is therefore almost impossible. In light of these considerable difficulties, the International Labour Organization consider that, for the purposes of general discussions of these, sheltered workshops might best be understood as a conceptual idea rather than a definite employment policy (2003). It is therefore important to note that the term sheltered work, as it is used herein, denotes that act of placing predominantly people with intellectual disabilities in sheltered employment or work facilities where they are subject to atypical working conditions, for an extended period of time.

These defining markers are chosen based on their prevalence across welfare and employment systems globally, but other common indicators exist. For example, as is evident from their name, sheltered workshops are facilities that are 'sheltered' from general or regular work settings, often even geographically located in insulated and isolated places. These work settings are usually run by non-governmental organizations, for-profit or charitable organizations, either privately or on behalf of the State (Samoy and Waterplas 1992). Commonly, these protected environments almost exclusively provide work for people with disabilities, alongside other disabled people (Mallender et al. 2015). The tasks are usually carried out under the instruction of supervisors or 
trainers, involving the employment of persons without disabilities to support production and regulate the working environment. Comparative studies have discerned that with a few exceptions, sheltered work implies a manufacturing industry, often on a sub-contract basis (OECD 1992, 2003). The simple work activities undertaken can range from clerical activities to, assembling, packing, woodwork, manufacturing, servicing, sewing, or sheet metal work (Miglioire 2010). Other reports however point to the meaningless nature of the work conducted in the sheltered workshop (Holmqvist 2009).

The differences in approaches, on the other hand, prove to be perhaps one of the most discernable problems when discussing the phenomenon of sheltered work. These are also significant and arise from the varied approaches and opposing views as to the purposes and objectives of the sheltered workshop. Tracing the history of these institutions reveals that largely sheltered work settings have evolved from religious or medical institutions and were therefore run according to an ethos of charity and medical treatment. As a result, sheltered workshops, besides their employment and work objectives, can often continue to be regarded as therapeutic, rehabilitative, or specialist training provisions and are intertwined with States' health and social policy measures. This hybrid of treatment, training, and work interventions gives sheltered work settings a broad mandate and makes comparisons difficult and at times confusing.

Accordingly, such settings can also operate according to varied ideologies and headings, which can range from 'Work Centre' in the US to 'Occupational Activity Centre' in Portugal. Such irregularity can lead to unclear or confusing legal statuses, rendering participants in these systems as eternal clients or patients, as opposed to fully fledged workers (Visier 1998; Mallender et al. 2015). Particularly in Eastern European States, this has had alarming effects, where people remain isolated and exploited in sheltered workshops that are run as large institutions (Franičević 2008). Elsewhere, these uncertainties concerning sheltered workshop attendees has resulted in court cases taken by individuals challenging their non-worker status in Germany, Austria, and France with varied success (Court of Justice of the European Union 2013).

These cases and claims of exploitation are also often linked to debates over pay and wages in sheltered workshops. Despite national minimum wage regulations, these are often exempt from such regulations, as they are usually not regarded to be a typical work environments. This is the direct consequence of denying workers in sheltered workshops the formal recognition of their employment status (OECD 1992). Advocacy organizations, however, arguing for equal rights contend that some participants in sheltered workshops are entitled to receive a minimum wage because their working conditions are comparable to that of an employee (Inclusion Ireland 2007). The issue of pay is therefore a particularly controversial one, which has been fuelled by recent media reports revealing that the CEOs of sheltered industries and charities receive six-figure salaries, yet continue to exploit their workers in the US and in Ireland by paying sub-minimum wages (Holland 2007; Schecter 2013; Deegan 2015).

A review of the quantitative data available showed that across 24 American states on average sheltered workers earned $\$ 101$ per month for approximately $74 \mathrm{~h}$ of work per month (Migliore et al. 2007). Low wages are a characteristic of sheltered workshops beyond the U.S. and a persistent feature of sheltered workshops on a global scale. In fact, most comparative research studies on sheltered work address the issue of low remuneration received by participants (Samoy and Waterplas 1992; Visier 1998; Mallender et al. 2015). The issue of payment has also been bought to the attention of international bodies such as the International Labour Organization, which heard a complaint against Japans 'welfare factories' alleging that their workers' low wages violated the relevant ILO Conventions (ILO 2009).

There are, however, opponents to the idea of paying sheltered workshop workers a minimum wage, as well as staunch advocates of the segregated system in general (Price 2016; Moore 2017). These represent more protectionist views of disability policy generally. This camp argues that, without such facilities, people would be left stranded with nothing to do. Moreover, without legislative exemptions, these would not be sustainable as a business, as sheltered workshops are generally not profit-making businesses. In fact, some run at a loss and are heavily reliant on state subsidies and 
grants. Others argue that the discussions over low wages in sheltered workshops are moot, as the payments received are not comparable to a wage, rather they are top up payments, received in addition to benefit payments ( $\mathrm{O}^{\prime}$ Reilly 2007). Others contend that sheltered workshops must continue as some individuals with disabilities will never receive a proper wage due to their inability to be economically productive and perform work of economic value (Corley 2014). Sheltered workshops then at least offer protection from the open labour market and a place for people with disabilities to meet.

Disability scholars have, however, pushed back on these views, arguing that they merely support archaic assumptions that people with intellectual disabilities are unable to work and therefore contribute meaningfully to their societies. This has led Visier (1998) and Taylor (2003) to denounce the sheltered workshop system because it fails to serve people with disabilities but rather contributes to their stigmatization as unproductive, worthless citizens. Even where the sheltered workshop is primarily intended to rehabilitate and treat its participants, disability is largely perceived as an 'incapacity', a label which, as Bach (2016) notes, the sheltered workshop only serves to foster, rather than remedy. Additionally, contrary to the aims of reducing obstacles to employment, the result of sheltered work placements and the effect of segregation often lowers expectations and enhances negative public attitudes making it more difficult for individuals to transition into meaningful employment (Kregel and Dean 2002). As a result of these low transition rates (in Germany, the rate is lower than $1 \%$ ), persons with disabilities remain in sheltered employment, isolated from their communities (Gottlieb et al. 2010).

Bach (2016) remarks that workplace research shows that intellectually disabled individuals are often more loyal, reliable, and have lower rates of absenteeism compared to other workers. It is then not only the inappropriate wages or low transition rates that are a major factor in the sheltered workshop controversy, but the very reasoning behind the concept of sheltered and segregated workspaces. Unsurprisingly disability activists identify that it is often the negative perceptions and the persistent, underlying perception that people with intellectual disabilities are best segregated, as the toughest barriers to overcome (National Center for Learning Disabilities 2014). This is because, to many, a sheltered workshop placement represents an act of being 'sorted out' and separated from mainstream settings and communities. Instead, a system of 'specialized', disability-specific interventions and 'care' applies, which denies many the opportunities and experiences available to non-disabled peers. This can then be the root of ensuing, consequential symptoms that lead to poverty and an overall inferior legal status. The sheltered workshop system on a whole has thus come to represent a practice that fails to respect people with intellectual disabilities and moreover one that is premised on the denial of rights and opportunities.

As a discrete and insular minority within society, people with intellectual disabilities have been subject to purposeful unequal treatment, institutionalized and segregated to a disproportionally greater extent than individuals without intellectual disabilities. Disability rights campaigners argue that the long-standing practice of placing people in separate, specialist facilities has caused their exclusion, which has been broad in its scope and purposeful (Campbell and Oliver 1996). Often this is a result of systematic policy approaches which are, arguably, fundamentally discriminatory. First, because the very act of placing only persons with disabilities in segregated institutions amounts to unequal treatment compared to those without disabilities who are not placed in these. Second, referring to the common markers and negative outcomes of the placements noted above, in effect those placed in sheltered work settings are often materially poorer and are often denied the same rights as other workers. Overall, attaining substantively equal outcomes for workers in sheltered workshops compared to workers in open and competitive employment is almost impossible. A factor which is aggravated by the length of the placement.

This paper will proceed to argue that this experience of exclusion is largely based on the unchallenged notion that segregation is an inevitable consequence of living with a disability. This exclusion, however, interferes with the equal enjoyment of human rights generally and constitutes a violation of people's dignity. In this way, traditional equality models that consider how to achieve 
equality for other minority groups have been unable to include the characteristic of intellectual disability in their scope. In response to this shortcoming, this paper argues that we need to revert to the basic promises of equality and human rights law in our attempt to conceptualize an approach to equality that includes people with intellectual disabilities, using the Convention as a framework. This approach will rely on determining that every individual possesses an equal right to have their inherent dignity respected and to lead a dignified life. Using this as the litmus test of equality, this paper will attempt to question whether, considering that the experience of segregation that is so endemic to the practice, sheltered work infringes upon individuals right to lead a dignified life and otherwise interfere with the enjoyment and protection of their rights.

\section{Equality}

Indeed the practice of sheltered work throws up important debates. This includes considering whether or not such practices are inherently discriminatory, considering the endemic concerns and negative consequences of such placements that largely result from segregation, an integral part of the sheltered work experience. However, discussing whether it is fair or not requires a more contextual debate that reflects on disability equality generally, as well as one that considers the case of intellectual disability specifically. This is undoubtedly necessary considering that, throughout the evolution of equality, the conceptual shifts between formal, procedural, and substantive equality approaches have often failed to reflect on the intricacies of intellectual disability. This is largely due to the limited platforms on which people with intellectual disabilities have been able to advocate for their equal rights and thrash out the meaning of equality from their perspectives. As a result, people with 'severe' disabilities have been excluded from seminal discussions of justice and traditional equality. The field of disability discrimination has thus remained under-theorized and left wanting (Clifford 2014).

Perhaps this is because, in considering the application and limits of existing equality theories in terms of their sensitivity to the case of intellectual disability, we realize that it is still largely expected and accepted that this group will inhabit segregated spaces. Not only does the blanket segregation of this entire group go largely unchallenged, but it is often widely justified based on the group's (perceived) innate inability to attain the merit-worthy attributes to be considered as an 'equal' in the first place (Rioux 1994). These operational (mis-)conceptions as to their ability and therefore their eligibility are perhaps the biggest challenge to equality claims that people with intellectual disabilities face. Undeniably then, any discussion over whether segregation is still an acceptable form of discrimination must build upon practicable, if differentiated notions of equality and its overarching purpose. This will help us in our debate intended to reconsider the practice of sheltered work.

\subsection{Is Segregation a Form of Discrimination?}

Where academic attention has been paid to discussing how equality and disability intersect, Colker (2009) notes that 'separate' has often been considered as 'unequal' by disability campaigners. Increasingly this has also led to claims that to segregate persons with disabilities from their communities is a violation of their human dignity. Undeniably, these claims have supported arguments to close large, residential institutions and end the horrific practices therein (Brignell 2010). This has particularly gained footing in the US with the help of the landmark Olmstead (United States Supreme Court 1999) decision, which determined that people had the (human) right to receive services in the most integrated setting available (Flores 2017). This case was argued on the basis that the unnecessary segregation of persons with disabilities was a violation of their dignity and constituted a form of discrimination contrary to the Americans with Disability Act [1990]. While such a definitive statement of discrimination may not be as easily made in other jurisdictions lacking a similarly powerful civil rights bill, what we can learn from this American example is how central the idea of dignity to disability rights considerations is (Wohl 2016). The concept of dignity and its necessity for a good life featured heavily in finding that the unnecessary segregation wrongly denied 
individuals their right to access the community and their right to receive services in the least restricted setting (Caley 2010).

Disability scholar Degener (2016b), like Bach, notes that there are some underlying notions intrinsic to the sheltered workshops system that reveal a particularly harmful misconception about 'disability' that consequentially interfere with the respect for an individual's inherent dignity. These create a significant prejudice and serve to continuously justify the segregation of people with disabilities. Degener traces the use of segregated facilities such as sheltered workshops and their legitimacy back to a reliance on particularly two assumptions associated with the notoriously problematic medical model view of disability. This model describes an approach to disability that still determines the disability policy landscape today and continues to have a detrimental impact on the human rights claims of persons with intellectual disabilities under the cloak of protectionism. The first is that disabled persons, above all else, require medical interventions, shelter, and welfare services; a need that can override any consideration for the inherent dignity and autonomy of individuals; and the second is that impairment can preclude legal capacity and interfere with the eligibility for rights claims. In combination, these assumptions distract from the idea that people with intellectual disabilities can make rights claims and that their segregation is inherently discriminatory.

Unsurprisingly then, not everyone is convinced that segregating people into sheltered workshops is the result of discrimination that is harmful and therefore objectionable. Colker (2009) and Brennan-Krohn (2016) for example believe in the need to retain a reliance on disability-specific institutions regardless of whether these interfere with a person's right to choose, lead a dignified life, or effectively segregate certain groups from the rest of society. These equality theorists identify a need for practical approaches to disability policy that acknowledge and reflect upon the 'real differences that sometimes accompany disability' (Brennan-Krohn 2016). Similarly, bioethicists Asch, Blustein, and Wasserman contend (Asch et al. 2008) that the way in which Western society is currently organized, it is inevitable that some people will continue to have their needs singularly met by institutional arrangements.

Explaining why this will particularly continue to apply to people with intellectual disabilities, Brennan-Krohn (2016) elaborates that, while a fully accessible world in which all persons are included and where the difference of disability is fully nullified might be 'relatively easy to imagine for a person who uses a wheelchair', for a person with profound impairments, affecting their ability to interact and communicate, this will be much more difficult to achieve. According to this reasoning, it is then unlikely that the differential treatment of persons with complex disabilities will ever be challenged holistically. In other words, their segregation in a sheltered workshop is not regarded as discriminatory, primarily because they will never be able to take up any other form of employment and therefore be eligible for any other legal status than that of a passive participant, regardless of the substantial disadvantages of the sheltered work placement. The difference of their disability is simply deemed to be too profound to ever warrant any other form of service provision or full entitlement to the range of rights claims that others enjoy. Segregation is then not regarded as a form of discrimination but and inevitable consequence of disability and goes largely unchallenged.

\subsection{Equality and Intellectual Disability-An Unhappy Liaison}

The pursuit of equality through time has largely focused on ensuring equal rights to all citizens. As a result of this pursuit an interdependent relationship between two modes of rights has developed. This sees an intermingling and interdependence of equality of treatment, i.e., negative, legal rights, and positive, social rights to pursue substantive equality which may indeed require special treatment on a discriminatory basis. Disability scholars agree however that beyond the remit of the formalsubstantive dimensions of equality, making rights tangible for people with intellectual disabilities requires additional attention (Silvers 1995; Reicher 2011). In fact, the traditional framework of rights has been notoriously weak in enforcing or protecting the rights of persons with intellectual disabilities. Undoubtedly, this is in part influenced by the preoccupation with solutions and remedies that comprise 
measurable entities that quantify what an equal outcome entails. These are premised on somewhat subjective opinions of justice and injustice and of what is fair and unfair. As noted above, 'intellectual disability' has then simply not been able to satisfactorily adhere to these binary understandings.

Young and Quibell (2000) consider that this difficultly largely stems from the fact that equality law in the Western, liberal tradition has focused too much on its subjects as autonomous individuals and on the protection of this autonomy from state interference. The individualistic nature of rights according to the liberal design presupposes that all rights holders are self-determining, independent agents. To the detriment of those who may require supports to act and make decisions, this requirement has systematically excluded some persons from the benefits of rights enjoyment and protection. As a result, certain groups who are deemed incapable of rational thought or autonomous agents quickly become ineligible; persons with intellectual disabilities especially have therefore been cast off as non-rights holders.

Although for some groups this illegitimate status may have been rectified over time (Winter 2003), persons with intellectual disabilities are still categorically deemed unqualified to be respected legal actors and rights holders because they are considered to lack autonomy or the ability for independent thought (Goodley and Katherine 2016). This is largely because, as Silvers (2005) acknowledges, these concepts are built on normative ideals and ideologies of normalcy that foster an apparition of a 'species typicality' upon which an eligibility standard is determined. Carlson (2001) similarly identifies that this standard is the product of 'cognitive ableism', a term coined by Carlson to describe the prejudice and the oppression of people with intellectual disabilities resulting from the bias towards individuals that seemingly demonstrate a normative cognitive ability.

The experience of exclusion then largely manifests itself owing to the perception that the intellectual disability characteristic entails an inherent, insurmountable difference-insurmountable in so far that no existing equality mechanism has been able to account and negate the challenges posed by the difference it represents. These are also considered too great to be accommodated by any legal or regulatory mechanism. Minow (1990) considers how in law the difference posed by intellectual disability is treated as intrinsic and solely regarded in terms of its bearing on the individual in question. All too readily then the exclusion experienced is regarded as an inevitable and natural consequence of living with impairment. The differential treatment in the form of segregation based on intellectual disability thus features as a part of legitimate employment and rehabilitation policies (Sheppard 2017).

The unchallenged nature of these dominant and rigid legal frameworks and policies compounds the unequal and unfair treatment of people with intellectual disabilities, harboring their stigmatization and the notion that their exclusion is inevitable. The effects of such systemic inequality can quickly become cumulative with particularly negative consequences for those most marginalized and silenced. Segregation and exclusion therefore pose a deeper challenge to equality than perhaps conventional acts of discrimination. This is particularly the case if we consider that institutional placements so impedes the exercise of rights afforded to everyone else outside the institution, that the placement therein alone, as opposed to a community-based setting or in the 'least restrictive settings possible', has been considered an act of discrimination, as in the Olmstead case (Bliss and Wells 2012). In the absence of such strong case law outside of the U.S., it will be useful to consider how the Convention will bear upon the arguments of how sheltered work intersects with the rights of persons with intellectual disabilities.

\subsection{Equality and Dignity in the CRPD}

The principle of equality is firmly rooted in international human rights law and is also central in the Convention. ${ }^{1}$ As the leading norm therein, the principle of equality pursued in the treaty bestows

1 Article 1 of the CRPD establishes that the purpose of the Convention is to 'promote, protect and ensure the full and equal enjoyment of all human rights and fundamental freedoms by all persons with disabilities, and to promote respect for their inherent dignity'. 
upon all persons an equal recognition and protection, securing all human rights to all persons on an equal basis. This follows the dogma of human rights law generally which understands that all rights are owed equally to all human beings by virtue of their common humanity. Theoretically then, there was perhaps no need for a new Convention, as existing treaty law incorporated people with disabilities in its protection. In their practical implementation, however, existing instruments were so broad and generic that certain 'grey areas' left particular groups effectively unprotected (MacKay 2006). In fact, similar to national equality frameworks, the 'universal' human rights regime had not proved to be all that effective in the context of disability, primarily because the conception of equality applied was not 'disability sensitive' enough to incorporate all individuals, and significant violations of individuals' dignity remained commonplace (Arnardóttir 2009). The Convention's main purpose was then to rectify this shortcoming by firmly placing a more substantive conception of equality at the centre of its provisions and clearly articulating a legal right to equality on behalf of persons with disabilities. Undeniably, it has been successful in achieving this and demonstrates a thorough re-interpretation of equality, based on the express adaptation of universal human rights to the unique situation of disability.

The Convention primarily re-envisions equality by emphasizing the basic principles of human rights law generally. In doing so, it reiterates the principles of equal concern and respect for each human being based on their shared and common humanity. This recognition is extended to decisively include all persons with disabilities, identifying that human rights are rights inherent to each human being and that all individual must be equally recognized as rights bearers and agents under the law. Moreover, the overall tenor and the rationale of the CRPD draws heavily on the core principles of integrity, dignity and the respect for difference which acknowledges that 'disability' is an integral part of humanity and contributes to human diversity (Bickenbach 1999).

Closer consideration of the Convention's general principles, as laid out in Article 3, thus reveals how the Convention embraces perhaps the most novel and dynamic conception of equality available at treaty level. ${ }^{2}$ This article is pivotal as it is intended to guide the interpretation of the Convention as a whole, but also clarify how its individual articles are to be transposed into national legislation. The Convention anticipates that this will require multiple equality tools, demonstrating a thorough understanding of existing approaches and incorporating broad, philosophical notions of autonomy, independence, and respect for difference. Further evidence of how the Convention embraces its equality mandate is found in nearly every article that reiterates the importance of inclusion and the requirement that the rights therein can be enjoyed on an equal basis with others, focusing on accessibility and participation as supporting mechanisms. Moreover, the Convention presupposes procedural equality, expressly refers to equality of opportunity, and at times anticipates equality of results. The Convention also explicitly refers to practical policy tools to assist in achieving equality such as reasonable accommodation, affirmative action, 'specific measures', and its prescriptive Article 5 on equality and non-discrimination. Overall, the Convention embodies a multi-layered approach devoted to the ideal of universal equality for all, whilst simultaneously aware that equality is a dynamic concept that must be 'tailored to the specific realities and experiences of those whom it is supposed to serve' (Arnardóttir 2009).

Besides its unique application of equality concepts and tools, the Convention signifies an awareness of the social construction of disability. Essentially, the treaty effectively highlights particularly the structural disadvantages that contribute to the experience of disability which it aims to dismantle. This central objective is outlined in the Convention's preamble (y), where it declares that it 'will make a significant contribution to redressing the profound social disadvantage of persons

2 The concepts addressed in Article 3 signify that all rights, duties and freedoms are to be granted and implemented according to the principles of: '(a) the respect for inherent dignity, individual autonomy including the freedom to make one's own choices, and independence of persons; (b) non-discrimination; (c) full and effective participation and inclusion in society; (d) respect for difference and acceptance of persons with disabilities as part of human diversity and humanity; (e) Equality of opportunity; (f) Accessibility' ( . . ) . 
with disabilities'. This is reflective of the social model of disability in which, as is widely known, the CRPD is rooted (Degener 2016a).

Perhaps the most transformative effect of this recognition of the need to challenge existing approaches and the resulting social disadvantages is, as Arstein-Kerslake (2014) aptly describes, that individuals with disabilities are no longer seen as passive recipients of 'special', 'protectionist', and largely segregated care. Central to the success of this Convention is the recognition that people with disabilities are rights holders in their own right, regardless of ability. Instead, the acknowledgement and protection of rights is unconditional and based on the sole premise of our shared humanity; eligibility is thus inconversant with merit. The Convention thus embodies a new conception that views individuals with disabilities not as ineligible and unqualified but 'as an equal who has been systematically marginalized and excluded from society and for whom State Parties must work for and with to achieve substantive equality' (Arstein-Kerslake 2014).

The Convention has then not only promoted global reform in disability policy towards the creation of more equal societies, but it also indicates how the concept of equality itself has evolved. Quite decidedly, it presents an approach to disability equality that bears upon the fundamental construct of human rights, requiring a restoration of the principles of equal respect for dignity and the identification of our collective, societal responsibility in achieving purposeful and meaningful lives. The Convention thus finally makes the 'dignity paradigm' a fundament of equality (Kalb 2011) by making a purposeful theoretical distinction between treating people equally (or decidedly unequally) in the distribution of resources and treating them as equals. It simultaneously also reiterates the universality, indivisibility, and inter-relatedness of all human rights according to the principle of universal, inherent dignity. Grant (2007) understands that the fundament of new human rights law owes to a reinterpretation of the 'equality of dignity paradigm', which acknowledges that equal respect and equal worth are the foundation for equal rights. Inevitably, considering sheltered work in a post-Convention era then requires discussing whether sheltered work and segregating practices are compatible with this focus now placed on the equal respect for inherent dignity, before anything else.

\section{The CRPD and Its Take on Sheltered Workshops}

Sheltered workshops and related practices were discussed during the drafting stages of the Convention. In fact, provided how frequently these were referred to in the contributions by each delegation, it is surprising then that sheltered work, often referred to as 'alternative work settings', were not mentioned in the final text. Besides the frequency, the transcripts of the discussions also reveal the discrepancies in approaches and attitudes towards disability held by delegations. These reflected the diverging approaches to disability policy that also manifest themselves in sheltered work practices with different, context-specific consequences for persons with intellectual disabilities. Accordingly, depending on the welfare and employment systems of the relevant delegations represented, these approaches ranged from paternalistic to inclusionist, from protectionist to rights-based interventions.

It is then particularly the discussions on sheltered work that reveal how these diverging attitudes and approaches came to head. In fact, the opinions differed to such an extent that the issue of sheltered workshops, and how, if at all, to deal with these in the treaty, were divided up until the very last minute of the drafting process. This reveals not only the political tightrope the Committee Chair, tasked with amending the draft text, had to walk, but also how widespread sheltered work practices are, as well as the views as to their purpose.

Overall, the transcripts reveal a general understanding amongst the negotiating community that people with intellectual disabilities experienced significantly higher levels of harmful discrimination and an extent of exclusion that remained largely unchallenged (United Nations Enable 2004a). However, only few delegations identified that the segregation resulting from placements in sheltered work settings where to be labeled as a wrongful from of discrimination and should thus be considered unacceptable. These opinions, largely voiced by (Disabled Persons Organizations (DPOs)), argued that sheltered work represented a form of unnecessary segregation, effectively leading to the exclusion of 
persons with disabilities. The practice was therefore an act of discrimination and was inconsistent with the very purpose of the Convention. Advocates regarded the drafting of an international disability rights convention as an ideal opportunity to categorically denounce these.

Many DPOs spoke out in opposition of sheltered workshops generally, arguing that these keep people excluded and foster notions that people with intellectual disabilities cannot be meaningfully employed. These argued that sheltered workshops were an outdated concept that signified a form of institutionalization, representing an ongoing barrier to inclusion as evidenced by the low transition rates from these to open employment. The International Disability Caucus, a coalition of DPOs set up for the purposes of negotiating the Convention, called for the elimination of all forms of institutionalization even those intended to fulfill the right to work. Challenging the notion that sheltered work created work opportunities, they contended that such measures represent limitations and fail to protect the right to work and to gain a living by work which is freely chosen (International Disability Caucus 2004). People with Disability Australia (PWDA) clarified that the Convention must not be construed as creating rights to segregated employment because this merely contributed to the permanent 'warehousing' of persons with disabilities. Rather, the Convention must affirm the right to full participation in the mainstream labour market.

Dignity also featured as a crucial concept during the discussions on the right to work. Broadly referring to work and training in sheltered workshops or in other confined environments, Palestine noted that the CRPD must protect the right to work and must include a reference to work that is freely chosen or accepted and 'preserves dignity'(United Nations Enable 2004b). The World Network of Users and Survivors of Psychiatry also commented that the issue of free choice was integral to the right to work (United Nations Enable 2004a). Cameroon emphasized the importance of strengthening the promotion of paid employment and suggested changes that emphasized independent, as well as remunerative work. Canada suggested including stronger wording that ensured career opportunities for all people with disabilities on the open labour market (United Nations Enable 2004b).

Despite these State interventions commenting on the right to choice of work and access to work on the open labour market, New Zealand was one of the only State delegations that specifically called for the closure of alternative work settings. It held that the Convention must clearly signal that sheltered work and other forms of segregation were no longer acceptable. Referring to the historic segregation of persons with disabilities, New Zealand emphasized that protecting people from unnecessary segregation was a pivotal issue (United Nations Enable 2005). The Convention needed to be unambiguous in its position on sheltered work so as to avoid presenting State Parties with a choice between providing either inclusive or segregated services. DPOs agreed that anything that can be construed as justifying and institutions and arguments that maintained sheltered workshops only served to reduce the responsibility of State Parties to support people with disabilities into open employment (United Nations Enable 2006).

Other delegations held opposing views. Accordingly, sheltered workshops should continue to exist, as these were a means employed by States to fulfill the right to work. A coalition of National Human Rights Institutions spoke out in support of sheltered work. The coalition argued that, from a legal perspective, the concept of sheltered work could be viewed as fulfilling the requirement on both State Parties and employers to reasonably accommodate workers with disabilities in the labour market. The practice of sheltered work should be revered as a form of reasonable accommodation and endorsed as a valid equality tool. Others agreed that because sheltered workshops would continue to exist based on the continued demand, the priority of the present Convention should then be on regulating rather than denouncing these (United Nations Enable 2004b). As the standard setting body in the area of work and employment, the ILO heavily weighed in on these debates. It explained that the Convention must reflect the 'reality' that some people are unable to work on the open labour market and that many people with disabilities worked in 'protected workshops'. Provisions for these alternative forms of work must be made (United Nations Enable 2004a). A failure to mention alternative workplaces would only harm those most marginalized and run the risk of aggravating the precariousness of the 
work situations that persons with disabilities were engaged in. Namibia agreed that the Convention should urge States to regulate the sector effectively by standardizing the rules and governance of these, harmonizing them with those of typical work.

Seemingly aware of the arguments both for and against sheltered work, as well as the Convention's overall purpose, the World Network of Users and Survivors of Psychiatry issued some pragmatic solutions. It considered that, based on their prevalence, sheltered work is likely to continue; however, the economic exploitation that is rampant and endemic in the sector must be curbed through regulation. The group recommended that the role of health care and rehabilitation services in sheltered work must not be overlooked. It urged the Committee to take note that, all too often then, what is called 'rehabilitation' is often 'busy-work' imposed on people instead of real opportunities promoting full social participation (United Nations Enable 2005).

Evidently, there were mixed opinions on the role of sheltered workshops and what these represented. These ranged from seeing these as genuine places of work, which required the application of rights-based employment regulations, to regarding such places as the embodiment of historical disadvantages, the harmful segregation and exploitation faced by people with disabilities using protectionist interventions. These divergent opinions culminated in a disagreement on whether the Convention should generally support or denounce these.

The Chair of the drafting committee ultimately chose not to include any reference to sheltered work practices in the final text of the Convention. This decision was based on the concerns raised by the disability community that these ultimately constituted unnecessary segregation and required careful review. Given how feverishly this issue was debated, it is nevertheless surprising that any reference to sheltered work was entirely omitted. Weller (2011) notes that this is a rare occasion that exemplifies the use of a purposeful silence in the Convention. As a tool for negotiation, silence was occasionally used in this manner for political reasons. This helped avoid an impasse over certain, contentious issues that could jeopardize the success of the whole Convention. If a specific aspect or decision was hotly debated and no agreement could be reached, silence over the matter was then a means to circumvent the problem and maintain a consensus securing the success of the negotiations.

As a result, the Convention is silent on sheltered workshops, which does little to help us in our attempt to consider sheltered work through the Convention's new equality prism and question its discriminatory implications. In fact, this has indeed, quite detrimentally, even had the opposite effect. Its silence has left a wide margin for potential misinterpretations or misuse thereof. The failure to reach an agreement on sheltered work has meant that State Parties have enacted the Convention inconsistently. Exploiting its silence on the matter, some have interpreted the Convention as justifying the continuation of sheltered work practices or used to argue for more segregated work provisions. The right to work as one that is fulfilled by sheltered settings or as a form of reasonable accommodation then effectively overrides the Convention's overall objective of inclusion. The Convention's overall stance on sheltered work has thus been subject to conflicting interpretations. For example, Mallender et al. (2015; IGOS 2011), taking a similar view to the Coalition of National Human Rights Institutions during the negotiations, consider that sheltered workshops are a form of reasonable accommodation. Reporting to the European Parliament then, these researchers suggest that the Convention even sets a legal obligation on States to provide sheltered workshops. A look to the how the Convention's treaty body, the Committee on the Rights of Persons with Disabilities, has embraced this silence and what it has interpreted it to mean for sheltered work practices may be more useful.

\subsection{Concluding Observations, Sheltered Work Since the Adoption of the Convention}

The Convention's silence on the topic of sheltered work has also impacted the interpretations thereof by the treaty body itself. This has become evident over the years through the accumulation of international jurisprudence and growing high-level commentary based on the Convention. The CRPD publishes their opinions on State implementation reports in the form of Concluding Observations. 
These provide a suite of information on the state of disability reform since the adoption of the Convention in a given State and provide a unique insight into how the treaty has been interpreted both nationally and internationally, assessing its impact. On a broader scale, an analysis of the existing collection of Concluding Observations gives us perhaps the widest and most current impression of the sheltered work debate available. A review of these Committee reports clearly signals that sheltered work continues to dominate the field of employment services for specific groups and, as a result, their continued segregation and exclusion.

Commenting on the situation in Canada, the Committee noted that particularly women and young persons with disabilities remained in sheltered workshops (CRPD/C/CAN/CO/1) (Committee on the Rights of Persons with Disabilities 2017a). The prevalence of sheltered workshops in Slovakia and Serbia, including a significant rise in numbers of these in Bosnia Herzegovina, also caught the Committee's attention ((CRPD/C/SVK/CO/1) (Committee on the Rights of Persons with Disabilities 2016c); (CRPD/C/SRB/CO/1) (Committee on the Rights of Persons with Disabilities 2016d); (CRPD/C/BIH/CO/1) (Committee on the Rights of Persons Disabilities 2017b). It also remarked upon the increasing manifestation of a segregated labour market in Austria and Germany (CRPD/C/AUT/CO/1) (Committee on the Rights of Persons with Disabilities 2013) and that many other States used sheltered workshops and similar 'specialized' and segregated employment models to employ persons with disabilities (CRPD/C/BOL/CO/1) (Committee on the Rights of Persons with Disabilities 2016b).

Besides expressing concern over States' continued reliance on segregated systems to employ persons with disabilities, the Committee has also regularly expressed concern over the practices within such States. It often cited that minimal wages or other forms of payment received by workers were problematic (CRPD/C/AUT/CO/1) (Committee on the Rights of Persons with Disabilities 2013). The Committee, based on its observations, even considered that Hong Kong's sheltered workshops operated in a manner that violated Article 16 of the Convention that enumerated the right to freedom from exploitation, violence, and abuse. The Committee reached this conclusion based on the 'daily allowance' received by persons with disabilities working in sheltered workshops, which it found to be 'too low' and 'bordering exploitation' (CRPD/C/CHN/CO/1) (Committee on the Rights of Persons with Disabilities 2012). The Committee also expressed concern in relation to the practices in Occupational Activity Centres in Portugal, noting in particular the working conditions and the average wage received by workers with disabilities (CRPD/C/PRT/CO/1) (Committee on the Rights of Persons with Disabilities 2016a). The Committee also urged Korea and Germany to eliminate its sheltered workshops through 'immediately enforceable exit strategies'. (CRPD/C/DEU/CO/1) (Committee on the Rights of Persons with Disabilities 2015); (CRPD/C/KOR/CO/1) (Committee on the Rights of Persons with Disabilities 2014).

The collection of Concluding Observations reveal that the Committee has provided substantial and definitive commentary on sheltered or segregated employment structures. The Committee has overwhelmingly found that sheltered work and conditions thereof to be inconsistent with the Convention and contrary to human rights provisions therein. As a result, the Committee has consistently encouraged State Parties, many of which still heavily rely on sheltered work structures, to review such practices and related legislation and bring them in line with the Convention. At times, the Committee was even explicitly referred to the rights violations occurring in sheltered workshops. In light of its observations of Serbia, for example, the Committee required that the State dismantle its sheltered workshop system and ensure the respect of all rights at work, of all workers, 'in accordance with the Convention' (CRPD/C/SRB/CO/1) (Committee on the Rights of Persons with Disabilities 2016d). Similarly, the Committee encourages Portugal to review its practices and legislation concerning the operation of its Occupational Activity Centres, 'from a human rights perspective to bring them into line with the Convention' (CRPD/C/PRT/CO/1) (Committee on the Rights of Persons with Disabilities 2016a).

Despite the fact that, on these occasions, the Committee has expressed clear criticisms addressing the fact that some sheltered work practices were contrary to the provisions within the CRPD, it has 
not identified that the resulting experience of segregation itself was problematic. The Committee has therefore failed to address the experience of exclusion from an equality perspective. In relation to such a finding, in fact, the CRPD Committee has to date been quite conservative in its interpretations of the Convention. This is evident in its failure to explicitly call out the segregation experienced as part of the sheltered workshops placements as a form of discrimination itself. Arguably, this is a missed opportunity on behalf of the Committee to categorically denounce sheltered work practices and addressing how the ideologies therefore conflict with the aims of the Convention. While the Committee does refer to some problematic practices that may be the result of a sheltered work placement, such as differentiated wage payments and reduced working standards, it does not refer to the practice, nor the resulting segregation, as a form of discrimination itself.

\subsection{Exclusion as a Form of Discrimination in the CRPD}

While the Convention, and by implication the Committee, leave the vital question of sheltered work susceptible to (mis-)interpretations; the treaty elsewhere does specify that exclusion is an equality issue and potentially represents a form of discrimination. Under the Convention, State Parties are bound to ban discrimination on the basis of disability and must guarantee 'equal and effective legal protection against discrimination on all grounds' (Article 5(2), CRPD). Helpfully, Article 2 of the Convention clarifies that, specifically, some types of exclusion on the basis of disability shall be considered as a form of discrimination, specifically where it interferes with or has the effect of impairing or nullifying the recognition, enjoyment or exercise, on an equal basis with others, of all human rights and fundamental freedoms in the political, economic, social, cultural, civil or any other field' (Article 2, CRPD).

While Article 2 does not consider that all forms of exclusion are to be considered as discriminatory, it does suggest that it be tested for its implications. If these are so great as to impact upon the enjoyment of equal rights of persons with disabilities, then a finding of discrimination is present. Article 2 does not necessarily encourage an exploration of exclusion, which is rooted in any attention to dignity, or lend itself to a blanket statement that renders all segregation experienced in sheltered workshops as discrimination. Instead, it requires an assessment of the nuances and effect of each individual experience of segregation, in accordance with the Convention's overall commitment to a more substantive, tailored approach to equality. Representing a form of conditionality then, this has the potential of stifling the Convention's lofty aims of achieving greater, (unconditional) inclusion and increasing the social participation of all person with disabilities. Although the Convention employs an exciting combination of equality tools, it is ultimately still confined to their traditional functioning. This sees processes of equality subject to tried and tested mechanisms and existing anti-discrimination frameworks that are subject to the reservations thereof. Determining the equality implications of sheltered work is therefore not straightforward. Instead, a decision of whether the segregation experienced constitutes a form of discrimination will require an individual assessment of each claim and only elicit individual redress. The definition of discrimination as provided in Article 2 of the Convention is therefore only of limited significance in considering the practice of sheltered work as a whole.

\section{Conclusions}

This discussion takes the example of sheltered workshops to test the effectiveness of the Convention in challenging the segregation of people with intellectual disabilities. Sheltered workshops are chosen based on their notoriety as places of exploitation. Their controversial nature is long documented and has flared up debates addressing all aspects of equality. Linking the experience of segregation with the exclusion and social disadvantages experienced by people with intellectual disabilities, this paper questions the legitimacy of sheltered work in light of the Convention on the Rights of Persons with Disabilities. This required a discussion over how to better define equality for people with intellectual disabilities. It was argued that, because of the segregation experienced as a 
result of the placement in confined services with limited opportunities, sheltered work impedes upon participants' right to lead a life of equal worth and importance and their right to dignity.

The Convention then is committed to protecting the inherent dignity of all persons and employs innovative approaches to achieving disability equality. The Convention, however, does not grant us the satisfaction of a sweeping and explicit denouncing of sheltered work practices. As a result of complex negotiations, the CRPD has remained silent on the sheltered workshop debate. Without a clear position expressed therein, different interpretations of the Convention's bearing on these have been effected. As a result, the CRPD Committee are still addressing the same, known concerns of exploitation in regard to sheltered work that were identified during the negotiations. The Committee has at least used the Concluding Observations to point out, in certain instances, that sheltered workshops should be closed in favour of more open options.

Primarily, the difficulty in declaring that sheltered workshop placements are discriminatory lies in the varied and divergent definitions and purposes of these, which is in turn determined by dichotomous policy dimensions which can lie somewhere between rights-based and protectionist. As a result, the often conflicting interests representing protectionism on the one hand and autonomy on the other, which dominated the drafting of the Convention, continues to define the disability policy landscape today.

The Article 2 definition that includes exclusion as a potential form of discrimination is indeed a unique and exciting innovation of the Convention. However, as an interpretive provision, it is one that still exists within the confinement of traditional legal systems and requires individual tests for a finding of discrimination through the experience of exclusion. Each incident of segregation would then be tested for the harmful effect of that placement and its impact upon an individual's right to dignity and to lead a dignified life. This innovative definition cannot be used to challenge whole policies or argue for the closure of entire segregated systems.

Overall, the most prevalent employment services for persons with intellectual disabilities are still principally offered in segregated, institutional settings. Despite its novel and broad equality perspectives, the Convention has only had a limited bearing on the dichotomous power dynamics of the disability policy landscape. The non-discrimination and equality paradigms of the treaty, however noble and dignity-focused, has not effectively carried over to holistically address and the widespread exclusion of persons with intellectual disabilities who still largely inhibit separate spaces and lead segregated lives. One redeeming aspect originating from the Convention's framework is perhaps its potential in determining that exclusion and segregation in some circumstances is to be considered as discriminatory albeit only in individual cases. Therefore, while it cannot provide us with arguments for the blanket protection from segregation, the Convention may be used to provide individual rights protections and remedies.

Conflicts of Interest: The author declares no conflicts of interest.

\section{References}

Arnardóttir, Oddney Mjoll. 2009. A Future for Multidimensional Disadvantage Equality? In The UN Convention on the Rights of Persons with Disabilities: European and Scandinavian Perspectives. Edited by Oddny Mjoll Arnardóttir and Gerard Quinn. Leiden: Martinus Nijhoff, p. 41.

Arstein-Kerslake, Anna. 2014. Restoring Voice to People: Realizing the Right to Equal Recognition before the Law of People with Cognitive Disabilities. Galway: National University of Ireland.

Asch, Adrienne, Jeffrey Blustein, and David Wasserman. 2008. Criticizing and Reforming Segregated Facilities for Persons with Disabilities. Journal of Bioethical Inquiry 5: 157-67. [CrossRef]

Bach, Michael. 2016. Cited in Fuatai, Teuila. From Exploitation to Employment: Undoing Canada's Sheltered Workshop System. Rabble News, April 12.

Bickenbach, Jerome. 1999. Minority Rights or Universal Participation: The Politics of Disablement. In Disability, Divers-Ability and Change. Edited by Martha Jones and Lee Ann Basser. Leiden: Martinus Nijhoff. 
Bliss, Charles, and Talley Wells. 2012. Applying Lessons from the Evolution of Brown v. Board of Education to Olmstead: Moving from Gradualism to Immediate, Effective, and Comprehensive Integration. Georigia State Univeristy Law Review 26: 705-39.

Brennan-Krohn, Zoe. 2016. Employment for People with Disabilities: A Role for Anti-Subordination. Harvard Civil Rights-Civil Liberties Law Review 51: 239-72.

Brignell, Victoria. 2010. When the Disabled Where Segregated. The New Statesman. December 15. Available online: http:/ / www.newstatesman.com/society/2010/12/disabled-children-british (accessed on 13 January 2017).

Caley, Sylvia. 2010. The Olmsetad Decision: The Road to Dignity and Freedom. Georigia State Univeristy Law Review 26: 651-62.

Campbell, Jane, and Michael Oliver. 1996. Disability Politics: Understanding Our Past, Changing Our Future. Abingdon: Routledge.

Carlson, Licia. 2001. Cognitive Ableism and Disability Studies: Feminist Reflections on the History of Mental Retardation. Hypatia 16: 124-46. [CrossRef]

Clifford, Stacy. 2014. The Capacity Contract: Locke, Disability, and the Political Exclusion of "Idiots". Politics, Groups, and Identities 2: 90-103. [CrossRef]

Cohen, Rick. 2014. Are People with Disabilities Exploited in Sheltered Workshops? Nonprofit Quarterly, April 14. Colker, Ruth. 2009. When is Separate Unequal? A Disability Perspective. New York: Cambridge University Press.

Committee on the Rights of Persons with Disabilities. 2012. Concluding Observations on the Initial Report of China, Adopted by the Committee at Its Eighth Session (17-28 September 2012). CRPD/C/CHN/CO/1; Geneva: Committee on the Rights of Persons with Disabilities, para. 67.

Committee on the Rights of Persons with Disabilities. 2013. Concluding Observations on the Initial Report of Austria. CRPD/C/AUT/CO/1; Geneva: Committee on the Rights of Persons with Disabilities.

Committee on the Rights of Persons with Disabilities. 2014. Concluding Observations on the Initial Report of the Republic of Korea*. CRPD/C/KOR/CO/1; Geneva: Committee on the Rights of Persons with Disabilities.

Committee on the Rights of Persons with Disabilities. 2015. Concluding Observations on the Initial Report of Germany*. CRPD/C/DEU/CO/1; Geneva: Committee on the Rights of Persons with Disabilities.

Committee on the Rights of Persons with Disabilities. 2016a. Concluding Observations on the Initial Report of Portugal*. CRPD/C/PRT/CO/1; Geneva: Committee on the Rights of Persons with Disabilities.

Committee on the Rights of Persons with Disabilities. 2016b. Concluding Observations on the Initial Report of the Plurinational State of Bolivia*. CRPD/C/BOL/CO/1; Geneva: Committee on the Rights of Persons with Disabilities.

Committee on the Rights of Persons with Disabilities. 2016c. Concluding Observations on the Initial Report of Slovakia*. CRPD/C/SVK/CO/1; Geneva: Committee on the Rights of Persons with Disabilities.

Committee on the Rights of Persons with Disabilities. 2016d. Concluding Observations on the Initial Report of Serbia* CRPD/C/SRB/CO/1; Geneva: Committee on the Rights of Persons with Disabilities.

Committee on the Rights of Persons with Disabilities. 2017a. Concluding Observations on the Initial Report of Canada* CRPD/C/CAN/CO/1; Geneva: Committee on the Rights of Persons with Disabilities.

Committee on the Rights of Persons Disabilities. 2017b. Concluding Observations on the Initial Report of Bosnia and Herzegovina*. CRPD/C/BIH/CO/1; Geneva: Committee on the Rights of Persons with Disabilities.

Corley, Cheryl. 2014. Subminimum Wages for the Disabled: Godsend or Exploitation? National Public Radio, Morning Edition, April 23.

Court of Justice of the European Union. 2013. Case-316/13. Gérard Fenoll v Centre D'aide par le Travail 'La Jouvene', Association de Parents et D'amis de Personnes Handicapées Mentales (APEI) D'avignon. ECLI:EU:C:2015:200; Luxembourg: Court of Justice of the European Union.

Dague, Bryan. 2012. Sheltered Employment, Sheltered Lives: Family Perspectives of Conversion to Community-based Employment. Journal of Vocational Rehabilitation 37: 1-11.

Deegan, Gordon. 2015. Departing Rehab Staff got €3.2m in redundancy. The Irish Independent, November 4.

Degener, Theresia. 2016a. A Human Rights Model of Disability. In Routledge Handbook of Disability Law and Human Rights. Edited by Peter Blanck and Eilionoir Flynn. Abingdon: Routledge.

Degener, Theresia. 2016b. Disability in a Human Rights Context. Laws 5: 35. [CrossRef]

Diament, Michelle. 2011. Sheltered Workshops No Better than Institutions Report Finds. Disability Scoop, January 19. Available online: https:/ /www.disabilityscoop.com/2011/01/19/sheltered-workshops-report/11974/ (accessed on 23 January 2018). 
Dimopoulos, Andreas. 2010. Issues in the Human Rights Protection of Intellectually Disabled Persons. Abingdon: Routledge, p. 67.

Flores, Roseanne L. 2017. State Reform and Respect for the Rights of the Disabled People: A Reflection on the Olmstead Decision the Case of New York State. Cogent Medicine 4: 1-9. [CrossRef]

Flores, Noelia, Christina Jenaro, M. Begona Orgaz, and M. Victoria Martín. 2011. Understanding Quality of Life of Workers with Intellectual Disabilities. Journal of Applied Research in Intellectual Disabilities 24: 133-44. [CrossRef]

Franičević, Vojmir. 2008. Decent Work Country Report- Croatia. Geneva: ILO.

Goodley, Daniel, and Runswick-Cole Katherine. 2016. Becoming Dishuman: Thinking about the Human through Dis/Ability. Discourse: Studies in the Cultural Politics of Education 37: 1-15. [CrossRef]

Gottlieb, Aaron, William Myhill, and Peter Blanck. 2010. Employment of People with Disabilities. In International Encyclopedia of Rehabilitation. Buffalo: Center for International Rehabilitation Research Information and Exchange (CIRRIE).

Grant, Evadne. 2007. Dignity and Equality. Human Rights Law Review 7: 299-329. [CrossRef]

Holland, Kitty. 2007. Sheltered Workshops at the Centre for Exploitation Claims. The Irish Times, August 27.

Holmqvist, Mikael. 2009. Disabled People and Dirty Work. Disability E Society 24: 869-82.

Interest Group on Occupational Services (IGOS). 2011. Partnership Project: “Quality Work Settings for All”. Brussles: Interest Group on Occupational Services (IGOS), p. 34.

International Labour Organization (ILO). 2009. Report of the Committee Set up to Examine the Representation Alleging Non-Observance by Japan of the Vocational Rehabilitation and Employment (Disabled Persons) Convention, 1983 (No. 159), Made under Article 24 of the ILO Constitution by the National Union of Welfare and Childcare Workers. GB304/14/6, Mar. 2009. Geneva: ILO.

International Labour Organisation (ILO). 2011. Promoting Training and Employment Opportunities for People with Intellectual Disabilities: International Experience. Geneva: ILO, p. iii.

Inclusion Ireland. 2007. A Chance to Work: A Discussion Paper on Work and Employment Services and Supports Available to people with an Intellectual Disability. Dublin: Inclusion Ireland.

International Disability Caucus. 2004. Article 22 Right to Work, Prepared by the International Disability Caucus. Available online: http:/ / www.un.org/esa/socdev/enable/rights/documents/ahc6idcda22infosheet_000. doc (accessed on 17 May 2017).

Kalb, Johanna. 2011. Litigating Dignity: A Human Rights Framework'. Albany Law Review 74: 1725-38.

Kennedy, E. B. 2007. Govt 'failing exploited Disabled Workers. The Irish Times, November 12.

Kregel, John, and David H. Dean. 2002. Sheltered vs. Supported Employment: A Direct Comparison of Long-Term Earnings Outcomes for Individuals with Cognitive Disabilities'. Available online: http:/ / www.worksupport. $\mathrm{com} / \mathrm{main} /$ downloads/dean/shelteredchap3.pdf (accessed on 12 October 2017).

MacKay, Don. 2006. Statement on Behalf of New Zealand at the Adoption of the Convention on the Rights of Persons with Disabilities by the United Nations General Assembly on 13 December 2006. Available online: http:/ / www.un.org/esa/socdev/enable/convstatementgov.htm\#nz (accessed on 20 January 2017).

Mallender, Jacqueline, Quentin Liger, Rory Tierney, Daniel Beresford, James Eager, Stefan Speckesser, and Vahé Nafilyan. 2015. Directorate General for Internal Policies of the European Parliament, Policy Department A. Economic and Scientific Policy, Employment and Social Affairs. 'Reasonable Accommodation and Sheltered Workshops for People with Disabilities: Costs and Returns of Investments—Study for the EMPL Committee. Brussels: European Parliament.

Miglioire, Alberto. 2010. Sheltered Workshops. In International Encyclopedia of Rehabilitation. Edited by John H. Stone and Maria Blouin. Buffalo: Centre of international Rehabilitation Research Information and Exchange, Available online: http://cirrie.buffalo.edu/encyclopedia/en/article/136/ (accessed on 15 February 2016).

Migliore, Alberto, Davi Mank, Tara Grossi, and Patricia Rogan. 2007. Integrated Employment or Sheltered Workshops: Preference of Adults with Intellectual Disabilities, their Families and Staff. Journal of Vocational Rehabilitation 26: 5-19.

Minow, Martha. 1990. Making All the Difference: Inclusion, Exclusion and American Law. Ithaca: Cornell University Press.

Moore, James. 2017. Rosa Monckton, It Will Never Be Morally Right to Pay Those with Learning Disabilities below the Minimum Wage. The Independent, March 3. 
National Center for Learning Disabilities. 2014. The State of Learning Disabilities. New York: National Center for Learning Disabilities.

O'Reilly, Arthur. 2007. The Right to Decent Work of Persons with Disabilities. Geneva: International Labour Office.

Organization for Economic Co-operation and Development (OECD). 1992. Employment Policy for People with Disabilities. Labour Market and Social Policy Occasional Papers No. 8; Paris: OECD Publishing.

Organization for Economic Co-Operation and Development (OECD). 2003. Transforming Disability into Ability: Policies to Promote Work and Income Security for Disabled People. Paris: OECD Publishing.

Price, Rita. 2016. Families Fight to Keep Institutions, Sheltered Workshops Open. The Coloumbus Dispatch, April 15. Quinn, Gerard. 2009. A Short Guide to the United Nations Convention on the Rights of Persons with Disabilities. In European Yearbook of Disability Law: Volume 1. Edited by Gerard Quinn and Lisa Waddington. Cambridge: Intersentia.

Reicher, Stella. 2011. Human Diversity and Asymmetries: A Reinterpretation of the Social Contract under the Capabilities Approach. International Journal on Human Rights 8: 167-79.

Rioux, Marcia. 1994. Towards a Concept of Equality of Well-Being: Overcoming the Social and Legal Construction of Inequality. In Disability Is Not Measles: New Research Paradigms. Edited by Marcia Rioux and Michael Bach. Toronto: L'Institute Roeher.

Samoy, Erik, and Lina Waterplas. 1992. Sheltered Employment in the European Community. Leuven: Katholieke Universtieit Leuven \& Hoger Instituut voor de Arbeid.

Schecter, Anna. 2013. Disabled Workers Paid just Pennies an Hour- and its Legal. NBC News, June 25.

Sheppard, Colleen. 2017. Contesting Systematic Discrimination: Law and Organizational Change. Galway: Centre for Disabliity Law and Poliy, National Univeristy of Ireland, March 22.

Shima, Isilda, Eszter Zólyomi, and Asgar Zaidi. 2008. The Labour Market Situation of People with Disabilities in EU25. European Centre, Policy Brief (1). Vienna: European Center for Social Welfare Policy and Research.

Silvers, Anita. 1995. Reconciling Equality to Difference: Caring (f)or Justice for People with Disabilities. Hypatia 10: 30-55. [CrossRef]

Silvers, Anita. 2005. People with Disabilities. In The Oxford Handbook of Practical Ethics. Edited by Hugh LaFollette. Oxford: Oxford University Press.

Taylor, Steven. 2003. Workers with Disabilities Deserve Real Choices, Real Jobs. Available online: http:/ / www. accessiblesociety.org/topics/economics-employment/shelteredwksps.html (accessed on 14 March 2016).

United Nations Enable. 2004a. Daily Summary of Discussions Related to Article 22 Right to Work. New York: United Nations Enable, vol. 3,\#6.

United Nations Enable. 2004b. UN Convention on the Rights of People with Disabilities Ad Hoc Committee Daily Summary: A Service Made Possible by Landmine Survivors Network. New York: United Nations Enable, vol. 4, \#7.

United Nations Enable. 2005. Daily Summary of Discussion at the Fifth Session 3 February 2005, UN Convention on the Human Rights of People with Disabilities Ad Hoc Committee-Daily Summaries a Service Brought to You by RI (Rehabilitation International). New York: United Nations Enable, vol. 6, \#9.

United Nations Enable. 2006. Daily Summary of Discussion at the Seventh Session 25 January 2006, UN Convention on the Human Rights of People with Disabilities Ad Hoc Committee-Daily Summaries, a Service Brought to You by Rehabilitation International (RI). New York: United Nations Enable, vol. 8, \#8.

United States Supreme Court. 1999. Olmstead v. L.C., 527 U.S., 581, (1999). Washington: United States Supreme Court. Visier, Laurent. 1998. Sheltered Employment for Persons with Disabilities. International Labour Review 137: $347-65$. Weller, Penelope. 2011. The Convention on the Rights of Persons with Disabilities and the Social Model of Health: New Perspectives. Journal of Mental Health Law 74-84. [CrossRef]

Winter, Jerry Alan. 2003. The Development of the Disability Rights Movement as a Social Problem Solver. Disability Studies Quarterly 23: 33-61. [CrossRef]

Wohl, Alison. 2016. Competitive Integrated Employment as a Civil Right for People with Disabilities. Paper present at the LEAD Center Webinar, Washington, DC, USA, November 8.

Young, Damon, and Ruth Quibell. 2000. Why Rights Are Never Enough: Rights, Intellectual Disability and Understanding. Disability $\mathcal{E}$ Society 15: 747-64.

(C) 2018 by the author. Licensee MDPI, Basel, Switzerland. This article is an open access article distributed under the terms and conditions of the Creative Commons Attribution (CC BY) license (http:/ / creativecommons.org/licenses/by/4.0/). 